Отримано: 01.10.2020 p.

Прорецензовано: 15.10 .2020 р.

Прийнято до друку: 27.10.2020 р.

e-mail: tmatanova@gmail.com

DOI: $10.25264 / 2409-6806-2020-31-33-40$
Matanova T. Social online network platforms of Ukrainians in Bulgaria as a means for self-presentation and consolidation. Наукові записки Національного університету «Острозька академія». Серія «Історичні науки». Острог, 2020. Вип. 31. С. 33-40.

\title{
Tanya Matanova
}

\section{SOCIAL ONLINE NETWORK PLATFORMS OF UKRAINIANS IN BULGARIA AS A MEANS FOR SELF-PRESENTATION AND CONSOLIDATION}

Ukrainians in Bulgaria as many other international migrants use social network platforms in their everyday life. In the text will be studied online platforms used by Ukrainian migrants in Bulgaria for communication, consolidation and self-presentation. Conclusions are based on empirical material gathered in the period 20162020 mainly by means of semi-structured interviews and virtual ethnography methods.

Key words: Ukrainians in Bulgaria, Social online network platforms, self-presentation, consolidation.

\section{Таня Матанова}

\section{СОЦІАЛЬНІ МЕРЕЖІ УКРАЇНЦІВ В БОЛГАРІЇ ЯК ЗАСІБ СЕБЕПРЕЗЕНТАЦІї ТА КОНСОЛІДАЦЇ̈}

У статті аналізуються соиіальні мережі, якими часто користуються украӥниі в Болгарї, як засіб їхньої самопрезентачії та консолідачії. Наукова розвідка написана на основі емпіричних матеріалів, які були зібрані авторкою за 2016-2020 роки. У процесі дослідження було застосовано доволі широке коло методів, зокрема напівструктурованого інтерв'ювання та віртуальної етнографії.

Зроблено наголос на тому, що використання україниями в Болгарії різноманітних соиіальних мереж та онлайн-платформ створюе свого роду віртуальний простір, який сприяє збереженню украйнської національної ідентичності, популяризаиії української мови, підтримуванню контактів з Батьківщиною тощо.

Зазначено, що однією з найбільших емігрантських онлайн-платформ є «InterNations». Авторкою було проаналізовано віртуальну спільноту «InterNations in Sofia». Це дозволило встановити кількість зареєстрованих там осіб українського походження, визначити географію їхнього розселення на теренах Болгарії, зрозуміти сфери їхньої зайнятості та диферениіювати за віковими категоріями. Встановлено, що значною популярністю серед україниів у Болгарії користується соиіальна мережа «Facebook», де вони підтримують функиіонування 16 груп. Це групи офіиійних украйнських організацій в Болгарії та групи неформального характеру. У них висвітлюється інформація про роботу Посольства Украӥни в Болгарії, діяльність української громади, проведені ними акиії та інші відомості (можливості вивчення мови, подорожування, привітання з нагоди свят тощо). Вказується на те, що в умовах пандемії COVID-19, коли масові дійства були заборонені, саме иі Facebook-спільноти стали простором об'єднання українців в Болгарії для відзначення різних українських свят та підтримки начіональних традицій (наприклад, до Дня вишиванки відбувалося масове поширення фото- та відеоматеріалів із украӥнською символікою). Мовами комунікаиії виступають украйнська, болгарська та російська (в окремих групах дописи російською мовою заборонені). Зауважено, що подібного роду групи відсутні в соиіальній мережі «ВКонтакme».

Авторка робить висновки, щзо соиіальні онлайн-платформи слугують засобами самопрезентації діяльності украӥнців у Болгарії, а водночас вони також є чинниками їхньої консолідації та співпраці.

Ключові слова: українці в Болгарії, соціальні мережі, онлайн-платформи, самопрезентація, консолідаиія.

Online and computer-mediated-communication (CMC) is possible due to the ascending number of software programs for PC and mobile gadgets in which "the communication process is being realized among people by means of computers connected in a network in which messages are coded, kept, transmitted and 
decoded" [2, p. 15]. N. Baron differs two levels of CMC. The synchrony level refers to the time in which the communication happens: live (writing synchronically) or through exchange of messages in suitable time for both senders and receivers (non-synchronically). The second level is determined by the range of people involved in the communication - one-to-one (a message is directed to one person) and one-to-many (messages are supposed to be read by more people [8, p. 29; 4, p. 216]).

Several years ago, men communicated through programs for synchronic chatting as mIRC, ICQ, Yahoo Messenger, etc., or by sending emails non-synchronically, i.e. more popular was one-to-one communication. Nowadays more preferable are the plenty of programs and applications for internet communication through VoIP or chat - Facebook, Viber, Google Hangouts, Instagram, Twitter, Telegram, WhatsApp, Weibo, etc. - which are used for a communication with many people at the same time through synchronic and non-synchronic chatting. CMC leads to two main forms of virtual collectives: virtual groups and virtual communities which have in common that they are based on similar interests and the maintenance of interpersonal relationships through social network platforms.

\section{Research methods and techniques}

The empirical data was gathered in the period 2016-2020 mainly by means of semi-structured interviews and virtual ethnography methods, including analysis of different people's activities and narratives on websites, weblogs, Facebook, YouTube videos, etc., and the consequently constructed "internet-worlds" [13, p. 27]. Kozinets's method of netnography [19] has been applied as it allows the analysis of internet consumers' behavior as well as of online communities, consolidated through computer mediated communication. The method for analysis of these communities he calls "blended ethnography" as it combines virtual and classical ethnography and focuses on various social activities, regardless of spatial boundaries and of the presence of the researcher in the field of research [16, p. 6]. Heike Greschke speaks in this context about the non-participant observation comparing it with the lurking practice of people reading public information accessible online, what includes also the access to the users' computer constructed social lives [11;22] and their communication as members in different virtual, for example Facebook groups. Another adequate approach to study virtual group is that of the researcher as a "participant-experiencer" [27;28] who through this practice strengthens his position as an active collaborator of the researched group but could also observe the communication inside, respectively the (shared) members' behavior. For the processing of the written data, text- and content-analyses are applied as methodical frameworks because they focus on each individual situation and the statements of the actors.

Having in mind N. Aksonova's statement [1, p. 285] that there is a lack of studies on social networks used for communication by Ukrainian speaking migrants in Bulgaria, this research should be considered as a try to fill this gap. The text defends the thesis that participation in Facebook and other online platforms, on the one hand, opens possibilities for self-presentation and, on the other hand, brings opportunities for virtual consolidation by exchanging through the Internet useful information related to the quotidian life and immigration of Ukrainians in Bulgaria. These platforms construct a virtual area in which the participation through native language usage maintains the national identity, the contact to the homeland, and postings related to a national, folk, church or other Ukrainian holiday, for example, of people singing, dancing or wearing traditional clothes, contribute for the preservation of the Ukrainian cultural heritage in the virtual space.

\section{Ukrainians in Bulgaria and social internet platforms they use for communication}

Statistical data of the 2011 Population and Housing Census in Bulgaria shows that about 3000 people with Ukrainian citizenship live in Bulgaria and further 1789 persons perceive themselves as belonging to the Ukrainian ethnic group. Some of these Ukrainians, predominantly those living in or close Sofia, Plovdiv, Burgas and Varna, consolidate through the foundation of Ukrainian associations. Since the beginning of the $21^{\text {st }}$ century seven associations are founded - "Maty Ukraina" (Sofia, 2000), "Dobrudzha - Ukraina" (Dobrich, 2004), "Diaspora - Ukraina" (Burgas, 2003), Association "Ukrainska diaspora Balkan'ska sich" (Burgas, 2014), Bulgarian-Ukrainian Association "Chernomorie" (Varna, 2004), "Ukrainska kashta" (Silistra, 2004), Association of the Ukrainians in Bulgaria "Ukrainska diaspora" (Varna, 2014) and Ukrainian-Bulgarian Association "Plovdiv" (2012). In 2013 they all formed the Association of Ukrainian organizations in Bulgaria "Maty Ukraina" (Mother Ukraine). Even there are no recent statistics about the exact number of Ukrainians in Bulgaria, in their opinion their number has doubled or tripled since 2011. And several hundreds if not thousands are members of various online social networks. 


\section{Weblogs}

Weblogs or blogs are social platforms giving information about the blog-author. Having in mind that "Social media [...] demand replies" [21, p. 17], and in practice published textual, photo- and video-materials are shared, liked and commented, as a consequence, users interacting with each other construct social relationships and invisible groups on the Internet [12].

Among the Ukrainians in Bulgaria has been found however just one blogger who is also an active video logger.

Volodimir Krisaev (Wolk) who maintains a personal blog in Livejournal and a YouTube-channel both named "Outside the Window (За вікном)" moves to Bulgaria from Germany in 2017. Besides being an active player of the Ukrainian migrant football team "Danubian sich (Задунайська січ)" (2018) he is a keen traveler: "Everything that happens behind my "windows": home, car, camera - is the channel "Outside the window". In my dreams and in reality, I live on a journey. The theme of the channel is the travel and the little miracles that accompany them! What I see is filtering, removing the negative and highlighting the bright colors! I offer you to see the world with my eyes!" [30].

His blog informs the reader about his interests and quotidian practices. The review of his entries on his blog shows that he belongs to the group of "non-monetizers" who, withstanding the impact of the commercial imperatives interwoven in the previously non-commercial sphere of online activity, do not try to make money with their blogs [14, p. 4]. He uses his blog (https://wolk-2.livejournal.com/) as an open diary in which he shares his travel destinations, how the journey was, where he slept, what he ate, what he saw and felt. One can see that his postings include text and photo materials of his trips in Bulgaria and neighboring countries (Serbia, North Macedonia, Greece, etc.). Entries related to Bulgaria show beautiful elements of the Bulgarian nature (rock phenomena, waterfalls, tourist paths), museums and other sightseeing sites, Bulgarian town- and city-scapes as well as explanations of Bulgarian traditions (Grandmother Marta (Baba Marta) on $1^{\text {st }}$ March, Kukeri processions in Pernik region in January, etc.) in comparison to similar traditions in other countries, etc. His vlog-videos actually add sound and movement to the stories presented textually and photographically in the blog. In other words, the postings in his blog are constituents of his online autobiography which express his wish to share his experience as a migrant and a traveler in Bulgaria what in fact is useful information for newcomers and Ukrainians planning to migrate to Bulgaria.

\section{Virtual groups}

One and maybe the biggest network for virtual communities of people living not in their homeland is the internet platform InterNations (2007). It numbers almost four million members in virtual communities in 420 towns around the world, including Sofia [31]. Its platform enables easy contact to other compatriots from a given town and country of birth who being abroad share the same or similar problems. As a consequence, various groups and communities are formed and participants could find plausible information and services also in regard to the professional career development. As to the beginning of August 2020 the virtual community "InterNations Sofia" counts 231 persons of Ukrainian origin (born in Ukraine). An overview of the member' profiles reveals that they belong to different age groups, work in various companies in Bulgaria or elsewhere and live in Sofia, Plovdiv, Burgas, Nova Zagora, Dobrich, etc.

The author's internet research on social network sites used by Ukrainian migrants shows that the most popular and respectively most numerous are the virtual groups in the platform Facebook (no groups were found either in the platform "VKontakte"). As to the beginning of August 2020 Ukrainians in Bulgaria support sixteen Facebook groups. Regarding the formality of the groups they are informal ones created by Ukrainians in Bulgaria as well as formal groups linked to Ukrainian institutions such as schools, associations, etc.

For example, the Ukrainian Sunday school uses its Facebook group "Ukrainian Sunday school of Maty Ukraina Foundation, Bulgaria (Українська недільна школа при фундації «Мати Україна», Болгарія)” [37] to exchange school materials, photos and videos of the school lessons, indoor and outdoor activities. Additionally, the group "Ukrainian children club in Sofia, Bulgaria (Український дитячий клуб у Сoфiï, Болгарія)" [38] named firstly "Ukrainians in Sofia, Bulgaria (Українці в Софіï, Болгарія)", is used by Ukrainian mothers in Sofia who share activities and materials for education of children in Ukrainian language and culture.

Misleading could be for some Facebook users the names of regionally sounding groups like "Ukrainians in Burgas (Українці в Бургасі)" [44] or "Українці Варни - Украинците във Варна - Ukrainians in Varna Болгарія" [42] which are actually groups of local Ukrainian organizations. Just one of them explains it 
clearly as a detailed information: "Supporting group of the association "Ukrainian diaspora in Varna and Varna region" ukrvarna.com. Ukrainians who come to or live in Varna and other parts of Bulgaria enter the groups, communicate and share information. The group is created to help immigrants from Ukraine who have moved to live or work in Bulgaria or just plan to move" [42]. Similar is the case with the group labeled "Ukrainian-Bulgarian association "Plovdiv" (Українсько-болгарське товариство «Пловдів»)" [39] which is simultaneously a group of the local cultural association, but also of the connected with it Ukrainian Consulate in Plovdiv, that accepts as members Ukrainians and Bulgarians from Plovdiv and elsewhere.

The analysis of these groups and also the non-formal and non-institutional groups "Ukrainians in Sofia (Українці в Coфіï)" [46] and "Ukrainians in Varna! :)))) (Українці в Bapні! :)))))" [45] reveals that participants share besides travel offers, holiday greetings, language learning opportunities, job and rentapartment announcements but also video links of a Ukrainian storyteller, public actions of local Ukrainian communities and posts of the Ukrainian embassy in Bulgaria related to Bulgarian and Ukrainian festivities as well as to the ways of travelling from and back to Ukraine, especially during the coronavirus pandemic.

In Facebook could be found four groups which translated in English sound "Ukrainians in Bulgaria": «Українці в Болгарії» [43], «Українці Болгарії - Украинци в България - Ukrainians in Bulgaria» [41] and two groups named «Украинцы в Болгарии» [35]. It is worth pointing out that the number of new members for August 2020 has increased in the first group with more than 300 in comparison to the latter with 30 members. An overview of the entries in all groups shows that they have not only names in common but also the information posted in all of them is related to travel and holiday offers, questions regarding travelling (during the specific Covid-19 period as well) or the renewal of personal documents, job vacancies for Ukrainians, Ukrainian events in different Bulgarian towns and Bulgarian sightseeing sites as well. This corresponds exactly to the self-presentation of the most numerous group «Украинцы в Болгарии»: “Тhe group is created to help immigrants from Ukraine who have moved to live or work in Bulgaria or just plan to resettle. Communication without boundaries. Here you could discuss any topics that you find interesting, guided by only one principle - mutual respect" [35]. Regarding the topics of entries posted by members in the group (which current number of group members in August 2020 is more than 5800) in the period JulyAugust 2020 could be generalized that they are, of course, predominantly focused on the travelling and immigration during the Covid-19 pandemic situation, about possibilities to immigrate for work in Bulgaria, but also about a beauty contest for Mrs Burgas and the call to vote for an Ukrainian (business-)woman as well as an appeal for help for an Ukrainian family that offers services to cook homemade Russian or Ukrainian dishes. One of the announcements is of a woman searching for her brother: 'Please help! I can't call my brother since 19th August. His engine broke while he was driving. His boss does not give any explanations. Whom can I call in this case? Can I call the consulate?" [35]. Demographic data could be gathered from another posted question about the new place of residence: answered up and then by new members, it becomes known that Ukrainians in Bulgaria live in the towns Sofia, Varna, Dobrich, Burgas, Stara Zagora, Yambol, Vidin, etc.

Some of the Facebook groups as "Bulgaria-Ukraine to and fro (Болгарія-Україна туди-сюди. БългарияУкрайна натам-насам)" [33], "Bus Ukraine-Bulgaria (Автобус Україна-Болгарія <-> БългарияУкрайна <-> Украина-Болгария)" [32], "поездки Украина-Болгария (travels Ukraine-Bulgaria)" [34], "Ukraine Bulgaria air tickets (Україна Болгарія авіаквитки (Украина Болгария авиабилеты)" [36] are created mainly to be offered passenger services or tickets. Recently, conditions of minibus travels are being improved "above all for the Eastern region of Bulgaria. For Ukrainians in Burgas and Varna it is easier to travel to Ukraine than to Sofia if they need to renew their personal documents. There are special groups in Facebook in which are posted announcements... There are regular microbus carriers two-three times a week. Sometimes they come from Plovdiv or Sofia and travel to Kiev. There are vans travelling only during the day in so that it is not dangerous to drive at night on the roads. (...) Passenger services are offered most often by Ukrainians to Ukrainians or people interested in these destinations. Sometimes this type of travelling is chosen, although it lasts longer, but for example flights to Odessa are twice a week and you have to wait a lot at the airports and you cannot take much luggage" [30]. Respectively, these agencies offer also currier services "but every order is individual and must be negotiated with the driver" [33]. Publications in the group "Bulgaria-Ukraine to and fro (Болгарія-Україна туди-сюди. България-Украйна натам-насам)" [33] show that most offered are the routes Sofia-Odessa, Kyiv-Varna, etc. Every person travelling by car to and from cities in Bulgaria and Ukraine posts a news in the group. This group turns out to be especially useful for sharing of information related to the restrictions enforced due to the Covid-19 pandemic, such as 
the organized with the help of the Embassy of Ukraine transfer of Ukrainian citizens from and to Bulgaria as well as a delivery of humanitarian consignment to Ukrainian truck drivers quarantined in Turkey, but also the ingenious suggestion for a travel to Ukraine: "I go to Kharkiv on foot. I can take two travelers with me. Free of charge" [33].

Concerning the festive calendar there are many greetings posted for national holidays as the National Flag Day (23th August) or the Independence Day (24th August) but favorite are also online greetings for Christmas and Easter. Furthermore, Facebook groups are used as virtual podiums at the Embroidered Shirt (Vyshivanka) Day (3rd Thursday of May) - or any other national Ukrainian holiday - when in-person participation is not possible and people share photos or videos on which they are dressed with a vyshivanka [23]. In the spring of 2020 when massive face-to-face gatherings were prohibited because of the coronavirus pandemics it was actually the only possibility to celebrate and consolidate with others by sharing photos virtually.

\section{Conclusion}

In general, the low number of bloggers and vloggers and the high number of Facebook groups could be explained by the fact that the cutting-edge in 2006 when weblogs were used as a means of self-expression their role has been replaced recently by other easier to use social media as Facebook, Instagram, etc., whereas the first ones focus on sharing content on social networks and the focus of the latter is on photos.

Considering the mentioned above Facebook groups could be generalized that different members post various entries regarding the life in Bulgaria, the immigration and emigration processes and everything else of relevance for the person writing. The chat language in most of the Facebook groups is allowed to be Ukrainian, Russian, Bulgarian. In other groups members writing in Russian language are banned. The most dominant topics posted and discussed in the groups, regardless of the aims of a group, are related to the migration from Ukraine to Bulgaria, finding a job and a place to live. Except for specific groups seldom in the focus are topics on literature, family, nature, politics. Another undiscussed topic is food. In comparison to them food and its consumption are common topics in the Facebook groups of Germans in Bulgaria [6]. On the one hand, this could be due to the fact that Germans living now in Bulgaria are representatives of the current immigration of West-Europeans in Bulgaria - including people coming from Great Britain $[18 ; 10]$, Netherlands [9], Italy [3] that occurred predominantly since the beginning of 21 st century. In contrast, Ukrainians of different immigrant waves live in Bulgaria continuously since the beginning of the 20th century and even earlier [5] and Ukrainian products and dishes are present in Ukrainian and Russian restaurants and shops [see 25; 7].

Nevertheless, active membership in online groups as well as blogs and vlogs commenting gives the users possibilities to communicate in their native language, to extend their offline social network, to ask for help and support, and even to celebrate various holidays virtually. In such a context online group formations function as channels for virtual consolidation with other compatriots in the same or other country residence. Seen from another perspective, on the one hand, putting together the postings of Ukrainian Facebook group members in a patch-work brings a collage of the social identities of the participating Ukrainians which represent the image of the virtual group. On the other hand, bloggers and vloggers - and sometimes also other social network users - self-presenting their lifestyle 'weave' their online autobiographies [see also 15; $26 ; 20]$ and sociocultural identities and share them with others.

Even the research results are based on few examples, the conclusions and the empirical data could be used for further studies on social online platforms and their function as an instrument for communication, self-presentation and consolidation of Ukrainian or other international migrants in foreign ethnic and cultural settings.

\section{Список використаних джерел та літератури:}

1. Аксенова Н. «Другая» культура в Болгарии. Дриновский сборник. 2019. Т. 12. С. 284-287. Рец. на кн.: Матанова Т. «С две родини, два езика, две култури...». Поколението от смесен брак - идентичност и етнокултурни характеристики: монография: София, 2016. 269 с.

2. Атанасов П. Роля на компютърно опосредстваната комуникация за предизвикване и овладяване на репутационни кризи. Изследване на съдържанието на блогове, корпоративни и информационни сайтове, дискусионни и тематични форуми и социални мрежи, свързано с репутационни и управленски кризи: автореф. дис., СУ «Св. Климент Охридски». София, 2017. 25 с.

3. Домозетски Вл. Българи в Италия: миграционни профили, представи, заблуди. Български фолклор (под печат). 2020.

4. Коцев Р. За видовете интернет форуми по съдържание. Проглас. 2017. № 2. С. 216-226. 
5. Матанова Т. С двумя родинами, двумя языками, двумя культурами... Поколение смешанных браков идентичность и этнокультурные характеристики. София, 2015. 140 с.

6. Матанова Т. Немци в България. Общностни институции, социални мрежи, всекидневна култура. София, 2019. $111 \mathrm{c}$

7. Матанова Т., Пенчев В. Етнопредприемачество сред руската общност в България. Българска етнология. 2020. № 2. C. 155-175.

8. Baron N.S. Always On: Language in an Online World. Oxford, 2008. 289 p.

9. Bratanova E. Unwrapping Expats: Dutch Migrants in Bulgaria. Masterthesis University of Amsterdam Graduate School for Social Sciences. Unpublished. 2011.

10. Elchinova M. The British are Coming!: a Bulgarian Village facing EU Integration. Migrations from and to Southeastern Europe / eds. A. Krasteva, A. Kasabova, D. Karabinova. Ravenna, 2010. P. 177-190.

11. Greschke H.M. Bin ich drin? - Methodologische Reflektionen zur ethnografischen Forschung in einem plurilokalen, computervermittelten Feld. Forum: Qualitative Social Research. 2007. № 8(3). URL: http://www. qualitative-research.net/index.php/fqs/article/view/279/614 (Last accessed: 25.01.2018).

12. Herring S.C., Scheidt L.A., Wright E., Bonus S. Weblogs as a Bridging Genre. Information Technology \& People. 2005. № 18(2). P. 142-171.

13. Hine Ch.M. Virtual Ethnography. London, 2000. 192 p.

14. Hopkins J. Monetising the Dividual Self: The Emergence of the Lifestyle Blog and Influencers in Malaysia. Oxford, 2019. $236 \mathrm{p}$.

15. Howanitz G. Leben weben (Auto-)Biographische Praktiken russischer Autorinnen und Autoren im Internet. Dissertation an der Universität Passau. Bielefeld. 2020. 376 p.

16. JanowitzK.M. Netnographie. Ethnographische Methoden im Internet und posttraditionale Vergemeinschaftungen.

12. Tagung der Deutschen ISKO (International Society for Knowledge Organization) Wissensorganisation,

19.-21.10.2009, Bonn, 2011. URL: http://www.klaus-janowitz.de/pdf/NetnoISKOText.pdf(Last accessed: 24.08.2020).

17. Jenker J. Die qualitative Inhaltsanalyse: Kurzdefinition und wissenschaftliche Praxis. 2007. URL: https:// quasus.ph-freiburg.de/qualitative-inhaltsanalyse/ (Last accessed: 15.07.2020).

18. Kaneff D. Property and Transnational Neoliberalism: the Case of British Migration in Bulgaria. Accession and Migration: Changing Policy, Society, and Culture / eds. J. Eade, Y. Valkanova. Farnham; Burlington, 2009. P. 59-74.

19. Kozinets R. V. Netnography. Doing Ethnography Research Online. London, 2010. 232 p.

20. Lenhart A., Fox S. Bloggers: A Portrait of the Internet's New Storytellers. 2006. URL: http://www.pewinternet. org/files/old-media/Files/Reports/2006/PIP\%20Bloggers\%20Report\%20July\%2019\%202006.pdf.pdf (Last accessed: 25.01.2018).

21. Lovink G. Social Media Abyss: Critical Internet Cultures and the Force of Negation. Malden, 2016.220 p.

22. Mann C., Stewart F. Internet Communication and Qualitative Research. London, 2000. 272 p.

23. Matanova T. Vyshivanka Parade and Day of Vyshivanka: Old Elements, New Practices, Local Origin, Worldwide Extension. Between the Worlds: People, Spaces and Rituals. P. 1. / eds. Y. Erolova, M. Maeva, R. Popov, M. Slavkova. Sofia, 2019. P. 50-64. URL: http://iefem.bas.bg/wp-content/uploads/2019/10 /SlavkovaMaevaErolovaPopovEds..Between-the-Worlds.PeopleSpaces-and-Rituals2019.pdf (Last accessed: 25.09.2020).

24. Nowson Sc. The Language of Weblogs: A Study of Genre and Individual Differences. Edinburgh, 2006. URL: http://citeseerx.ist.psu.edu/viewdoc /download?doi=10.1.1.133.7968\&rep=rep1\&type=pdf (Last accessed: 25.01.2018).

25. Penchev V., Matanova T. Ukrainian Ethnic Entrepreneurship in Bulgaria. Folk Art and Ethnology. 2020. № 4 (386). P. 151-163.

26. Schwaemmlein E., Wodzicki K. What to Tell About Me? Self-Presentation in Online Communities. Journal of Computer-Mediated Communication. 2012. № 17. P. 387-407.

27. Walstrom M.K. Ethics and Engagement in Communication Scholarship: Analyzing Public, Online Support Groups as Researcher/ Participant-Experiencer. Virtual Research Ethics: Issues and Controversies. Hershey, 2004. P. 174-202.

28. Walstrom, M.K. "Seeing and Sensing" Online Interaction: An Interpretive Interactionist Approach to USENET Support Group Research. Online Social Research: Methods, Issues, and Ethics / eds. M.D. Johns, Sh.-L. Chen, G.J. Hall. New York, 2004. P. 81-97.

29. Interview with A.T. recorded by T. Matanova, 2019, archive number: AIF I No 584, a.u. 2.

30. За вікном. URL: https://www.youtube.com/channel/UCrgZv15RdNm5jEXummPcsmQ/about (Last accessed: 1.08.2020).

31. Internations. URL: https://www.internations.org/members/search /result?localcommunity=7 (Last accessed: 18.08.2020)

32. Автобус Україна-Болгарія <-> България-Украйна <-> Украина-Болгария. 3027 members (1.08.2020). URL: https://www.facebook.com/groups /1637763836491133/ (Last accessed: 29.08.2020).

33. Болгарія-Україна туди-сюди. България-Украйна натам-насам. 4411 members (1.08.2020). URL: https:// www.facebook.com/groups /1421781614779341/ (Last accessed: 29.08.2020).

34. Поездки Украина-Болгария. 460 members (1.08.2020). URL: https:/ /www.facebook.com/ groups/351339865553573/?ref=br_rs (Last accessed: 29.08.2020).

35. Украинцы в Болгарии. 1658 members (1.08.2020). URL: https://www.facebook.com/ groups/1397463030547978/?ref=br_rs (Last accessed: 29.08.2020).

36. Україна Болгарія авіаквитки (Украина Болгария авиабилеты). 287 members (1.08.2020). URL: https:// www.facebook.com/groups/755643761263763/?ref=br_rs, (Last accessed: 29.08.2020).

37. Українська недільна школа при фундації «Мати Україна», Болгарія. 61 members (18.08.2020). URL: https://www.facebook.com/groups /1661842044088260/ (Last accessed: 29.08.2020). 
38. Український дитячий клуб у Софіï, Болгарія. 88 members (1.08.2020). URL: https://www.facebook.com/ groups/486702071540494/ (Last accessed: 29.08.2020).

39. Українсько-болгарське товариство «Пловдів». 202 members (1.08.2020). URL: https:/www.facebook.com/ groups/consulukr/ (Last accessed: 29.08.2020).

40. Українці Болгарії - Украинци в България - Ukrainians in Bulgaria. 2881 members (1.08.2020). URL: https:// www.facebook.com/groups/311986819925/ (Last accessed: 29.08.2020).

41. Українці Болгарії - Украинци в България - Ukrainians in Bulgaria. 5275 members (1.08.2020). URL: https:// www.facebook.com/groups/uainbg/ (Last accessed: 29.08.2020).

42. Українці Варни - Украинците във Варна - Ukrainians in Varna Болгарія. 281 members (1.08.2020). URL: https://www.facebook.com/groups/ukrvarna /?ref=search (Last accessed: 29.08.2020).

43. Українці в Болгарії. 2331 members (1.08.2020). URL: https://www.facebook.com/groups/UkrainiansBulgaria/ (Last accessed: 29.08.2020).

44. Українці в Бургасі. 988 members (1.08.2020). URL: https:/ /www.facebook.com/groups/781050278575421/ (Last accessed: 29.08.2020).

45. Українці в Варні. 486 members (1.08.2020). URL: https://www.facebook.com/groups/564860640278492/ (Last accessed: 29.08.2020).

46. Українці в Coфiї. 370 members (1.08.2020). URL: https://www.facebook.com/groups/1082210695123292/ (Last accessed: 29.08.2020).

\section{References}

1. Aksonova N. «Druhaia» kultura v Bolharyy. Drynovskyi sbornyk. 2019. T. 12. S. 284-287. Rets. na kn.: Matanova T. «S dve rodyny, dva ezyka, dve kultury...». Pokolenyeto ot smesen brak - ydentychnost y etnokulturny kharakterystyky: monohrafyia: Sofia, 2016. 269 s.

2. Atanasov P. Rolya na kompyutarno oposredstvanata komunikatsia za predizvikvane iovladyavane na reputatsionni krizi. Izsledvane na sadarzhanieto na blogove, korporativni i informatsionnisaytove, diskusionni i tematichni forumi i sotsialni mrezhi, svarzano s reputatsionni i upravlenski krizi.Avtoreferat, SU «Sv. Kliment Ohridski», Fakultet po zhurnalistika i masova komunikatsia. Sofia, 2017. $25 \mathrm{~s}$.

3. Domozetski V. Balgari v Italia: migratsionni profile, predstavi, zabludi. Balgarski folklor (forthcoming). 2020.

4. Kotsev R. Za vidovete internet forumi po sadarzhanie. Proglas. 2017. № 2. S. 216-226.

5. Матанова T. S dvumia rodynamy, dvumia yazykamy, dvumia kulturamy... Pokolenye smeshannykh brakov ydentychnost y jetnokulturnye kharakterystyky. Sofia, 2015. $140 \mathrm{~s}$.

6. Matanova T. Nemtsi v Balgaria. Obshtnostni institutsii, sotsialni mrezhi, vsekidnevna kultura. Sofia, 2019. $111 \mathrm{~s}$.

7. Matanova T., Penchev V. Etnopredpriemachestvo sred ruskata obshtnost v Balgaria. Balgarska etnologiya. 2020. № 2. C. $155-175$.

8. Baron N.S. Always On: Language in an Online World. Oxford, 2008. 289 p.

9. Bratanova E. Unwrapping Expats: Dutch Migrants in Bulgaria. Masterthesis University of Amsterdam Graduate School for Social Sciences. Unpublished. 2011.

10. Elchinova M. The British are Coming!: a Bulgarian Village facing EU Integration. Migrations from and to Southeastern Europe / eds. A. Krasteva, A. Kasabova, D. Karabinova. Ravenna, 2010. P. 177-190.

11. Greschke H.M. Bin ich drin? - Methodologische Reflektionen zur ethnografischen Forschung in einem plurilokalen, computervermittelten Feld. Forum: Qualitative Social Research. 2007. № 8(3). URL: http://www. qualitative-research.net/index.php/fqs/article/view/279/614 (Last accessed: 25.01.2018).

12. Herring S.C., Scheidt L.A., Wright E., Bonus S. Weblogs as a Bridging Genre. Information Technology \& People. 2005. № 18(2). P. 142-171.

13. Hine Ch. M. Virtual Ethnography. London, 2000. 192 p.

14. Hopkins J. Monetising the Dividual Self: The Emergence of the Lifestyle Blog and Influencers in Malaysia. Oxford, 2019. $236 \mathrm{p}$.

15. Howanitz G. Leben weben (Auto-)Biographische Praktiken russischer Autorinnen und Autoren im Internet. Dissertation an der Universität Passau. Bielefeld, 2020. 376 p.

16. Janowitz K.M. Netnographie. Ethnographische Methoden im Internet und posttraditionale Vergemeinschaftungen. 12. Tagung der Deutschen ISKO (International Society for Knowledge Organization) Wissensorganisation, 19.-21.10.2009, Bonn, 2011. URL: http://www.klaus-janowitz.de/pdf/NetnoISKOText.pdf(Last accessed: 24.08.2020).

17. Jenker J. Die qualitative Inhaltsanalyse: Kurzdefinition und wissenschaftliche Praxis. 2007. URL: https:// quasus.ph-freiburg.de/qualitative-inhaltsanalyse/ (Last accessed: 15.07.2020).

18. Kaneff D. Property and Transnational Neoliberalism: the Case of British Migration in Bulgaria. Accession and Migration: Changing Policy, Societye, and Culture / eds. J. Eade, Y. Valkanova. Farnham; Burlington, 2009. P. 59-74.

19. Kozinets R. V. Netnography. Doing Ethnography Research Online. London, 2010. 232 p.

20. Lenhart A., Fox S. Bloggers: A Portrait of the Internet's New Storytellers. 2006. URL: http://www.pewinternet. org/files/old-media/Files/Reports/2006/PIP\%20Bloggers\%20Report\%20July\%2019\%202006.pdf.pdf (Last accessed: 25.01.2018).

21. Lovink G. Social Media Abyss: Critical Internet Cultures and the Force of Negation. Malden, 2016.220 p.

22. Mann C., Stewart F. Internet Communication and Qualitative Research. London, 2000. 272 p.

23. Matanova T. Vyshivanka Parade and Day of Vyshivanka: Old Elements, New Practices, Local Origin, Worldwide Extension. Between the Worlds: People, Spaces and Rituals. P. 1. / eds. Y. Erolova, M. Maeva, R. Popov, M. Slavkova. Sofia, 2019. P. 50-64. URL: http://iefem.bas.bg/wp-content/uploads/2019/10 /SlavkovaMaevaErolovaPopovEds..Between-the-Worlds.PeopleSpaces-and-Rituals2019.pdf (Last accessed: 25.09.2020). 
24. Nowson Sc. The Language of Weblogs: A Study of Genre and Individual Differences. Edinburgh, 2006. URL: http://citeseerx.ist.psu.edu/viewdoc /download?doi=10.1.1.133.7968\&rep=rep1\&type=pdf (Last accessed: 25.01.2018).

25. Penchev V., Matanova T. Ukrainian Ethnic Entrepreneurship in Bulgaria. Folk Art and Ethnology. 2020. № 4 (386). P. 151-163.

26. Schwaemmlein E., Wodzicki K. What to Tell About Me? Self-Presentation in Online Communities. Journal of Computer-Mediated Communication. 2012. № 17. P. 387-407.

27. Walstrom M.K. Ethics and Engagement in Communication Scholarship: Analyzing Public, Online Support Groups as Researcher / Participant-Experiencer. Virtual Research Ethics: Issues and Controversies. Hershey, 2004. P. 174-202.

28. Walstrom M.K. "Seeing and Sensing" Online Interaction: An Interpretive Interactionist Approach to USENET Support Group Research. Online Social Research: Methods, Issues, and Ethics / eds. M.D. Johns, Sh.-L. Chen, G.J. Hall. New York, 2004. P. 81-97.

29. Interview with A.T. recorded by T. Matanova, 2019, archive number: AIF I No 584, archive unit: 2.

30. Za viknom. URL: https://www.youtube.com/channel/UCrgZv15RdNm5jEXummPcsmQ/about (Last accessed: 1.08.2020).

31. Internations. URL: https://www.internations.org/members/search /result?localcommunity=7 (Last accessed: 18.08.2020).

32. Avtobus Ukraina-Bolhariia <-> Bъlharyia-Ukraina <-> Ukrayna-Bolharyia. 3027 members (1.08.2020). URL: https:/www.facebook.com/groups /1637763836491133/ (Last accessed: 29.08.2020).

33. Bolhariia-Ukraina tudy-siudy. Bъlharyia-Ukraina natam-nasam. (1.08.2020). URL: https://www.facebook. com/groups /1421781614779341/ (Last accessed: 29.08.2020).

34. Poezdky Ukrayna-Bolharyia. 460 members (1.08.2020). URL: https:/ /www.facebook.com/ groups/351339865553573/?ref=br rs (Last accessed: 29.08.2020).

35. Ukrayntsы $\mathrm{v}$ Bolharyy. 1658 members (1.08.2020). URL: https://www.facebook.com/ groups/1397463030547978/?ref=br rs (Last accessed: 29.08.2020).

36. Ukraina Bolhariia aviakvytky (Ukrayna Bolharyia avyabyletы). 287 members (1.08.2020). URL: https://www. facebook.com/groups/755643761263763/?ref=br rs (Last accessed: 29.08.2020).

37. Ukrainska nedilna shkola pry fundatsii "Maty Ukraina", Bolhariia. 61 members (18.08.2020). URL: https:// www.facebook.com/groups /1661842044088260/ (Last accessed: 29.08.2020).

38. Ukrainskyi dytiachyi klub u Sofii, Bolhariia. 88 members (1.08.2020). URL: (https://www.facebook.com/ groups/486702071540494/ (Last accessed: 29.08.2020).

39. Ukrainsko-bolharske tovarystvo "Plovdiv". 202 members (1.08.2020). URL: https://www.facebook.com/ groups/consulukr/ (Last accessed: 29.08.2020).

40. Ukraintsi Bolharii - Ukrayntsy v Bъlharyia - Ukrainians in Bulgaria. 2881 members (1.08.2020). URL: https:// www.facebook.com/groups/311986819925/ (Last accessed: 29.08.2020).

41. Ukraintsi Bolharii - Ukrayntsy v Bъlharyia - Ukrainians in Bulgaria. 5275 members (1.08.2020). URL: https:// www.facebook.com/groups/uainbg/ (Last accessed: 29.08.2020).

42. Ukraintsi Varny - Ukrayntsyte vъv Varna - Ukrainians in Varna Болгарія. 281 members (1.08.2020). URL: https:/www.facebook.com/groups/ukrvarna /?ref=search (Last accessed: 29.08.2020).

43. Ukraintsi v Bolharii. 2331 members (1.08.2020). URL: https://www.facebook.com/groups/UkrainiansBulgaria/ (Last accessed: 29.08.2020).

44. Ukraintsi v Burhasi. 988 members (1.08.2020). URL: https://www.facebook.com/groups/781050278575421/ (Last accessed: 29.08.2020).

45. Ukraintsi v Varni. 486 members (1.08.2020). URL: https://www.facebook.com/groups/564860640278492/ (Last accessed: 29.08.2020).

46. Ukraintsi v Sofii. 370 members (1.08.2020). URL: https://www.facebook.com/groups/1082210695123292/ (Last accessed: 29.08.2020). 